\title{
Germinal matrix cells: mimicker of blasts or small blue cell tumors in cerebrospinal fluid
}

\section{Weijie Li*}

Department of Pathology and Laboratory Medicine (DPLM), Children's Mercy Kansas City, UMKC School of Medicine, USA

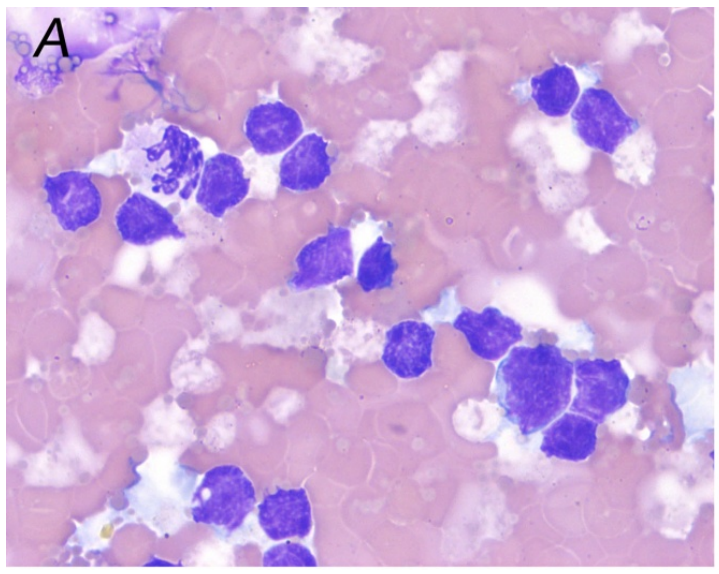

A two-week-old preterm (25-week gestation) female infant presented with difficult breathing. Ultrasound showed grade 3 bilateral intraventricular hemorrhage with ventriculomegaly. Lumber puncture was performed. Cerebrospinal fluid (CSF) cytospin showed many small to medium sized cells with round or irregular nuclei, densely dispersed nuclear chromatin, inconspicuous nucleoli and scant basophilic cytoplasm. These cells were scattered (panel A) or in clusters with nuclear molding (panel B). Monocytes or hemosiderin-laden macrophages are also present. The morphologic feature of these cells is suspicious for leukemia or small blue cell tumor such as medulloblastoma or primitive

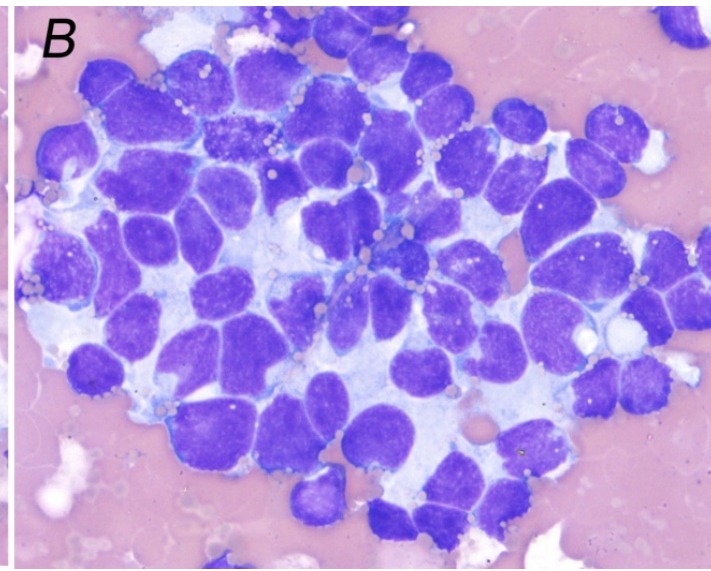

neuroectodermal tumor. Immunohistochemistry stains for CD34, CD10 and CD79a were negative. Germinal matrix hemorrhage was diagnosed. A right ventriculoperitoneal shunt was placed to relieve the hydrocephalus. Patient was clinically improved and discharged home.

The germinal matrix is the site of proliferating neuronal and glial precursors in the developing brain. The germinal matrix cells can be seen in the CSF of neonates or premature infants. They morphologically mimic blasts or small blue cell tumor. Recognition of these cells can avoid unnecessary tests and anxiety.
Copyright: (C2019 Li W. This is an open-access article distributed under the terms of the Creative Commons Attribution License, which permits unrestricted use, distribution, and reproduction in any medium, provided the original author and source are credited.
${ }^{\star}$ Correspondence to: Weijie Li, Department of Pathology and Laboratory Medicine (DPLM), Children's Mercy Kansas City, UMKC School of Medicine, 2401 Gillham Road | Kansas City, MO 64108, USA, Tel: (816) 234-3234; Fax: (816) 302-9944; E-mail: wli@cmh.edu

Received: April 01, 2019; Accepted: April 08, 2019; Published: April 10, 2019 